\title{
IMPLIKASI PENGENAAN PAJAK PENGHASILAN FINAL TERHADAP PENGHITUNGAN PAJAK PENGHASILAN BADAN PADA PT. EMPAT TUJUH ABADI JAYA
}

\author{
Yuyun Apriana Christian ${ }^{1}$, Grace B. Nangoi ${ }^{2}$, Novi S. Budiarso ${ }^{3}$ \\ 1,2,3 Jurusan Akuntansi, Fakultas Ekonomi dan Bisnis, Universitas Sam Ratulangi, Jl. Kampus Bahu, Manado, \\ 95115, Indonesia \\ E-mail : yuyunaprianach@gmail.com
}

\begin{abstract}
PP 462013 is a regulation issued by the government to provide convenience for SMEs taxpayers. Taxpayers who apply this regulation must have gross circulation below Rp. 4.8 billion. By using this regulation, taxpayers simply multiply the gross circulation in 1 month at the final rate of $1 \%$. The purpose of this study is to compare the income tax to be paid by using final income tax and income tax laws and to determine more efficient regulations to be implemented by PT. Empat Tujuh Abadi Jaya. The analytical method used in this study is descriptive qualitative. The results showed that the income tax of PT. Empat Tujuh Abadi Jaya based on the income tax law is Rp. 34,135,000.00, while based on the final 1\% income tax is Rp. 46,694,000.00. It can be concluded that it will be more efficient for PT. Empat Tujuh Abadi Jaya to pay income tax by using income tax laws because the amount of tax to be paid is smaller.
\end{abstract}

Keywords: Corporate Income Tax, Final Income Tax, PP 46 2013, SMEs, Calculation of Income Tax.

\section{PENDAHULUAN}

Keberadaan UMKM saat ini sedang berkembang dengan sangat pesat. Melihat hal ini, pemerintah berusaha untuk terus menyempurnakan kebijakan perpajakannya demi meningkatkan kesadaran wajib pajak. PP No. 46 Tahun 2013 adalah peraturan yang dikeluarkan oleh pemerintah bagi wajib pajak orang pribadi maupun badan yang memiliki usaha dengan peredaran bruto di bawah Rp4,8M. Peraturan ini dikeluarkan dengan maksud untuk meningkatkan kepatuhan wajib pajak, dalam hal ini wajib pajak UMKM. Meskipun tidak dikatakan secara langsung bahwa peraturan ini ditujukan bagi UMKM, namun hal ini dapat disimpulkan dari batas peredaran bruto yang dikenai yaitu $\mathrm{Rp} 4,8 \mathrm{M}$, sedangkan untuk batas peredaran bruto untuk UMKM adalah sebesar Rp50M. Peraturan ini memberikan kemudahan bagi wajib pajak karena dalam penghitungannya, wajib pajak hanya perlu mengalikan peredaran bruto dengan tarif pajak yaitu sebesar $1 \%$.

\section{TINJAUAN PUSTAKA}

Pajak

Pengertian Pajak. Menurut Sari (2013:34), pajak merupakan iuran dari masyarakat yang diberikan untuk negara, yang bersifat memaksa, yang wajib dibayarkan oleh wajib pajak berdasarkan peraturan perundang-undangan yang tidak memperoleh prestasi yang dapat secara langsung diberikan dan yang berguna untuk membayar pengeluaran sehubungan dengan tanggungjawab negara untuk melaksanakan pemerintahan.

Fungsi Pajak. Sari (2013 : 37) mengatakan, terdapat 2 fungsi utama pajak. Pertama, fungsi penerimaan (budgetair) yaitu pajak merupakan alat untuk memasukkan uang ke dalam kas negara yang bertujuan untuk membayar kebutuhan negara berupa pengeluaran secara rutin maupun kegiatan pembangunan. Kedua, fungsi mengatur (regulerend) yaitu pajak 
merupakan sarana dengan berbagai tujuan di bidang keuangan. Lewat kebijaksanaan pajak, pemerintah dapat mengatur pertumbuhan ekonomi negara.

Jenis-Jenis Pajak. Terdapat 3 jenis pajak menurut Resmi (2014: 7) yaitu, pajak menurut golongan terdiri atas pajak langsung dan pajak tidak langsung, pajak menurut sifat terdiri atas pajak subjektif dan pajak objektif, dan yang terakhir pajak menurut lembaga pemungut terdiri atas pajak negara dan pajak daerah.

Asas Pemungutan Pajak. Menurut Waluyo (2010: 13), ada beberapa asas dalam melakukan pemungutan pajak diantaranya: Equality, Certainty, dan Economy

Syarat Pemungutan Pajak. Mardiasmo (2018 : 4) mengatakan bahwa jika ingin kegiatan memungut pajak tidak ada hambatan, maka kegiatan memungut pajak harus berdasarkan syarat-syarat, diantaranya: (1) adil dalam pemungutan (syarat keadilan); (2) Undang-undang menjadi dasar pemungutan (syarat yudiris); (3) perekonomian tidak terganggu (syarat ekonomis); (4) efisien dalam pemungutan pajak (syarat finansial); dan (5) sederhana dalam sistem pemungutan.

Sistem Pemungutan Pajak. Resmi (2014 : 11) mengatakan bahwa dalam pemungutan pajak terdapat 3 sistem pemungutan, yaitu: (1) Official Assessment System; (2) Self Assessment System; dan (3) With Holding System.

Wajib Pajak. Menurut UU No.28 Tahun 2007, wajib pajak adalah orang pribadi atau badan, yaitu orang yang membayar pajak dan pemungut pajak yang memiliki hak serta kewajiban mengenai pajak berdasarkan ketentuan perpajakan.

Jenis Tarif Pajak. Suandy (2011 : 7) mengatakan, terdapat empat tarif pajak, yaitu tarif sebanding atau proporsional, tarif progresif, tarif degresif, dan tarif tetap.

\section{Pajak Penghasilan}

Pengertian Pajak Penghasilan. Resmi (2014 : 74) mengatakan, pajak penghasilan merupakan pajak dalam suatu tahun pajak yang dikenakan atas penghasilan yang didapatkan oleh wajib pajak.

Subjek Pajak Penghasilan. Berdasarkan Pasal 2 UU No. 36 Tahun 2008, subjek pajak dibagi atas 2, yaitu subjek pajak dalam negeri dan juga subjek pajak luar negeri. Yang menjadi subjek pajak dalam negeri antara lain, orang pribadi, badan, serta warisan. Sedangkan dalam Undang-Undang No. 17 Tahun 2000, yang bukan merupakan subjek pajak antara lain, organisasi-organisasi internasional, konsulat ataupun pejabat lain yang berasal dari negara asing, kantor perwakilan negara asing, serta pejabat perwakilan diplomatik dan pejabat-pejabat perwakilan organisasi internasional.

Objek Pajak Penghasilan. Definisi objek dari pajak penghasilan, berdasarkan pasal 4 UU No.36 Tahun 2008 merupakan: Seluruh tambahan kemampuan ekonomis yang berasal dari dalam negeri maupun yang berasal dari luar negeri yang didapatkan atau diperoleh oleh wajib pajak, dengan bentuk serta nama apapun, yang bisa digunakan untuk kebutuhan dan kepentingan wajib pajak maupun untuk menimbun kekayaan wajib pajak yang bersangkutan.

Tarif Pajak Penghasilan. Pasal 17 UU PPh menjelaskan tentang tarif yang dipakai untuk menghitung pajak penghasilan. Subjek pajak/ wajib pajak yang termasuk dalam undangundang adalah wajib pajak orang pribadi dalam negeri dan wajib pajak badan dalam negeri atau bentuk usaha tetap.

1. Tarif Pajak Untuk Wajib Pajak Orang Pribadi

\begin{tabular}{lc}
\multicolumn{1}{c}{ PKP } & Tarif \\
\hline Sampai dengan Rp. 50.000.000 & $5 \%$ \\
Rp. 50.000.000- Rp. 250.000.000 & $15 \%$ \\
Rp. 250.000.000- Rp. 500.000.000 & $25 \%$ \\
Di atas Rp. 500.000.000 & $30 \%$ \\
\hline
\end{tabular}


2. Tarif Pajak Bagi Wajib Pajak Badan

Untuk wajib pajak badan dalam negeri dan Bentuk Usaha Tetap (BUT), tarif pajak yang ditetapkan adalah sebesar 28\%. Sejak tahun 2010, tarif ini diturunkan menjadi $25 \%$. Bagi wajib pajak yang berbentuk perseroan terbuka dalam negeri yang sahamnya dperdagangkan di bursa efek Indonesia dari jumlah keseluruhan paling sedikit $40 \%$ serta memenuhi ketentuan tertentu lainnya mendapatkan pengurangan tarif sebesar 5\% dibandingkan tarif yang berlaku. Menurut Pasal 31E dalam ayat 1 UU PPh dikatakan, wajib pajak badan dalam negeri yang memiliki omzet atau peredaran bruto kurang dari Rp50M dapat mengurangkan tarif 50\% dari tarif yang dikenakan atas penghasilan kena pajak dari bagian peredaran bruto sampai dengan Rp4.800.000.000,00.

Pajak Penghasilan Final Berdasarkan Peraturan Pemerintah Nomor 46 Tahun 2013. Wajib pajak orang pribadi maupun wajib pajak badan, yang tidak termasuk BUT dan yang mendapatkan penghasilan atas usaha yang dijalankan dengan omzet atau peredaran bruto paling banyak $\mathrm{Rp} 4.8 \mathrm{M}$ dalam 1 tahun pajak, akan dikenai tarif $1 \%$ berdasarkan peraturan pajak penghasilan yang bersifat final.

Subjek Pajak Penghasilan Final 1\%. Yang menjadi subjek pajak penghasilan final $1 \%$ antara lain:

1. Wajib pajak yang bersifat orang pribadi serta wajib pajak badan selain BUT.

2. Wajib pajak yang mendapatkan penghasilan atas usaha dan selain penghasilan dari jasa yang termasuk dalam pekerjaan yang bersifat bebas bebas, serta omzet atau peredaran bruto yang diperoleh dalam 1 tahun pajak tidak melebihi Rp4.8M.

Objek Pajak Penghasilan Final 1\%. Objek pajak pada PPh final 1\% adalah seluruh penghasilan atas usaha yang dijalankan yang didapatkan oleh wajib pajak namun tidak lebih dari Rp4.8M pada 1 tahun pajak. Peredaran bruto atau omzet yang dimaksud dalam peraturan ini adalah jumlah seluruh gerai, baik pusat atau cabangnya.

Dasar Pengenaan Pajak Penghasilan Final 1\%. Dasar pengenaan pajak dalam menghitung $\mathrm{PPh}$ final $1 \%$ merupakan omzet atau peredaran bruto dari usaha yang dijalankan dalam 1 tahun pajak yang terakhir sebelum tahun pajak tersebut. Jika peredaran bruto atau omzet kumulatif dalam suatu tahun pajak sudah lebih dari Rp4,8 Miliar, wajib pajak hanya dikenakan pajak penghasilan final 1\% sampai akhir tahun pajak. Pada tahun berikutnya, wajib pajak akan dikenai pajak penghasilan berdasarkan ketentuan umum undang-undang pajak penghsilan.

Pajak Penghasilan Final Berdasarkan Peraturan Pemerintah Nomor 23 Tahun 2018. Peraturan Pemerintah Nomor 23 Tahun 2018 merupakan revisi dari Peraturan Pemerintah Nomor 46 Tahun 2013. Peraturan pemerintah ini resmi diberlakukan pada 1 Juli 2018. Jika sebelumnya pemerintah menetapkan tarif $1 \%$ pada pengusaha UMKM, dalam peraturan ini pemerintah menurunakan tarifnya menjadi $0,5 \%$. Tujuan di turunkannya tarif Pajak Penghasilan (PPh) bagi UMKM ini adalah untuk mendorong masyarakat untuk turut serta dalam kegiatan ekonomi negara, untuk memberikan kemudahan bagi wajib pajak dalam menjalankan kewajiban perpajakannya, lebih memberikan keadilan, memberikan kesempatan bagi wajib pajak untuk memberikan kontribusinya bagi negara, serta untuk menambah pengetahuan masyarakat tentang pentingnya pajak bagi bangsa dan negara. Berikut adalah pokok-pokok penting yang diatur dalam peraturan pemerintah nomor 23 tahun 2018:

1. Tarif PPh Final 0,5\% Bersifat Opsional.

2. Pengenaan tarif $\mathrm{PPh}$ final $0,5 \%$ memiliki batas waktu.

3. Wajib pajak yang dikenai $\mathrm{PPh}$ final $0,5 \%$ memiliki peredaran bruto di bawah $\mathrm{Rp} 4,8$ Miliar.

4. Wajib Pajak yang tidak bisa untuk mengenakan $\mathrm{PPh}$ final $0,5 \%$ adalah wajib pajak yang bersifat orang pribadi yang memperoleh penghasilan dari usaha jasa sehubungan dengan pekerjaan bebas, wajib pajak dengan penghasilan yang berasal dari luar negeri yang 
memiliki pajak terutang atau yang telah dibayar di luar negeri, wajib pajak yang penghasilannya telah dikenakan pajak penghasilan yang bersifat final lainnya, dan wajib pajak yang memperoleh penghasilan yang tidak termasuk sebagai objek pajak.

Kriteria UMKM (Usaha Mikro, Kecil dan Menengah). Kriteria Usaha Mikro, Kecil dan Menengah berdasarkan UU dibagi menurut jumlah aset dan omzet yang dipunyai dalam suatu usaha. Usaha mikro merupakan usaha yang mempunyai paling banyak Rp50.000.000,00 kekayaan bersih selain tanah dan bangunan dan hasil penjualan paling banyak dalam satu tahun Rp300.000.000,00. Usaha kecil merupakan usaha yang mempunyai Rp50.000.000,00-Rp500.000.000,00 kekayaan bersih selain tanah dan bangunan dan mempunyai hasil penjualan dalam satu tahun Rp300.000.000,00-Rp2.500.000.000,00. Usaha menengah merupakan usaha yang mempunyai kekayaan bersih Rp500.000.000,00Rp10.000.000.000,00 selain tanah dan bangunan dan mempunyai hasil penjualan Rp2.500.000.000,00-Rp50.000.000.000,00.

Penelitian Terdahulu. Menurut Haryati dan Noviari dalam penelitiannya pada PT. XYZ, dikatakan bahwa hasil penelitian menunjukkan jumlah pajak penghasilan PT. XYZ dengan menerapkan PP No. 46 Tahun 2013 adalah sebesar Rp6.415.800,00. Sedangkan dengan menerapkan UU No. 36 Tahun 2008, jumlah pajak yang harus dibayarkan oleh PT. XYZ adalah sebesar Rp0 karena adanya kerugian yang dialami oleh PT. XYZ.Berbeda dengan penelitian yang dilakukan oleh Haryati dan Noviari, penelitian yang dilakukan Sindari, Dianaswara dan Arniati yang dilakukan pada PT. Trio Infotek Batam menunjukkan bahwa perusahaan akan lebih diuntungkan jika menerapkan PP No. 46 Tahun 2013. Pajak PT. Trio Infotek Batam dengan menerapkan PP No. 46 Tahun 2013 adalah sebesar Rp10.791.700,00, sedangkan apabila menerapkan UU No. 36 Tahun 2008 adalah sebesar Rp16.785.250,00. Selisih pajak antara PP No. 46 Tahun 2013 dan UU No. 36 Tahun 2008 cukup besar, yaitu Rp5.993.550,00. Melihat hal ini dapat disimpulkan bahwa meskipun memberikan kemudahan bagi wajib pajak, namun nyatanya tidak semua wajib pajak diuntungkan dengan diberlakukannya peraturan ini. Untuk wajib pajak yang dalam usahanya mendapat kerugian, peraturan ini hanya akan memberatkan. Hal ini disebabkan karena peraturan ini tidak memberikan toleransi bagi perusahaan yang sedang mengalami kerugian.

\section{METODE PENELITIAN}

Jenis Penelitian. Penelitian ini menggunakan jenis penelitian deskriptif kualitatif. Dalam penelitian ini, peneliti mendeskripsikan situasi dan menganalisis permasalahan yang ada, kemudian menjabarkannya dalam bentuk kata-kata.

Tempat \& Waktu Penelitian. Penelitian ini dilakukan pada PT. Empat Tujuh Abadi Jaya yang beralamatkan di Jl. R.W. Mongisidi Lingkungan 1 Kelurahan Malalayang Satu, Kecamatan Malalayang, kota Manado. Dengan waktu penelitian dimulai sejak Agustus 2018 sampai dengan Oktober 2018.

Jenis Data Penelitian. Dalam penelitian ini, data kualitatif berisi hasil wawancara seperti sejarah instansi, visi serta misi, struktur organisasi dan juga penerapan penghitungan pajak penghasilan PT. Empat Tujuh Abadi Jaya. Data kuantitatif dalam penelitian ini berisi hasil dari dokumentasi berupa data laporan keuangan dan neraca tahun 2017 PT. Empat Tujuh Abadi Jaya.

Sumber Data Penelitian. Dalam penelitian ini, data primer didapatkan dengan cara melakukan wawancara dan dokumentasi secara langsung pada PT. Empat Tujuh Abadi Jaya. Sedangkan data sekunder dalam penelitian ini berupa data penunjang tinjauan pustaka maupun bahan penelitian lain yang didapatkan dari buku, literatur dan lainnya.

Metode Pengumpulan Data. Wawancara dilakukan oleh peneliti kepada pimpinan PT. Empat Tujuh Abadi Jaya mengenai gambaran umum perusahaan dan penerapan penghitungan pajak penghasilan yang dilakukan oleh PT. Empat Tujuh Abadi Jaya. 
Sedangkan, dokumentasi dilakukan oleh peneliti dengan cara mengumpul dokumen berhubungan dengan objek penelitian berupa data laporan keuangan dan neraca tahun 2017 PT. Empat Tujuh Abadi Jaya.

Metode dan Proses Analisis. Metode analisis data yang digunakan dalam penelitian ini adalah metode deskriptif kualitatif. Metode ini bertujuan untuk menguraikan, menggambarkan serta kemudian menganalisis implikasi dari diterapkannya pajak penghasilan final terhadap pajak peghasilan PT. Empat Tujuh Abadi Jaya. Tahap pertama, peneliti akan mengumpulkan data-data yang diperlukan dalam penelitian ini. Data akan diambil dari PT. Empat Tujuh Abadi Jaya dengan cara melakukan wawancara dan mendokumentasikan data yang diperlukan untuk kegiatan penelitian. Langkah selanjutnya, peneliti akan membahas data yang telah didapatkan serta menghitung jumlah pajak penghasilan PT. Empat Tujuh Abadi Jaya dengan menggunakan undang-undang pajak penghasilan dan pajak penghasilan final. Setelah mengolah data yang telah didapatkan, peneliti akan menganalisis inplikasi dari diterapkanya pajak penghasilan final terhadap pajak penghasilan PT. Empat Tujuh Abadi Jaya. Selanjutnya penulis akan membuat kesimpulan atas pembahasan dan perhitungan yang sebelumnya telah dilakukan oleh penulis. Tahap akhir yang dilakukan oleh penulis adalah memberikan saran apabila penulis menemukan hal yang dapat diperbaiki agar menjadi lebih baik lagi dari sebelumnya.

\section{HASIL PENELITIAN DAN PEMBAHASAN}

\subsection{Hasil Penelitian}

PT. Empat Tujuh Abadi Jaya adalah perusahaan yang bergerak di bidang peternakan khususnya peternakan ayam petelur yang terletak di kota Manado. PT. Empat Tujuh Abadi Jaya didirikan pada tanggal 9 Oktober tahun 2016. Penjualan utama dari perusahaan ini adalah telur ayam. Namun melihat peluang yang ada, pengelola juga mengembangkan usaha penjualan ayam daging dan penjualan pupuk dari kotoran ayam. PT. Empat Tujuh Abadi Jaya terletak di Jl. R.W. Mongisidi Lingkungan I Kelurahan Malalayang satu, kecamatan Malalayang, Kota Manado, Sulawesi Utara dengan nomor telepon 0811-4325-425.

Penghitungan Pajak Penghasilan Berdasarkan UU Pajak Penghasilan. Dari laporan laba rugi PT. Empat Tujuh Abadi Jaya perlu dilakukan koreksi fiskal karena terdapat perbedaan perlakuan penghasilan maupun biaya antara akuntansi komersial dan akuntansi pajak. Akun yang perlu dikoreksi fiskal antara lain:

1. Biaya Pengobatan Karyawan dan Biaya Konsumsi Karyawan. Biaya pengobatan karyawan dan biaya konsumsi karyawan tidak dapat diakui sebagai biaya pengurang penghasilan. Oleh karena itu, dalam rekonsiliasi fiskal, akun biaya pengobatan karyawan dan biaya konsumsi karyawan harus dikoreksi positif sebesar Rp15.000.000,00 untuk biaya pengobatan karyawan dan Rp54.000.000,00 untuk biaya konsumsi karyawan.

2. Biaya Penyusutan Kendaraan. Biaya penyusutan kendaraan berdasarkan akuntansi komersial sebesar Rp55.714.280,00, sedangkan biaya penyusutan kendaraan berdasarkan akuntansi perpajakan sebesar Rp48.745.000,00. Oleh karena itu perlu dilakukan koreksi negatif sebesar: Rp55.714.280,00 - Rp48.745.000,00 = Rp6.969.280,00.

3. Biaya Penyusutan Bangunan. Biaya penyusutan bangunan berdasarkan akuntansi komersial sebesar Rp31.200.000,00, sedangkan biaya penyusutan kendaraan berdasarkan akuntansi perpajakan sebesar Rp15.600.000,00. Koreksi negatif yang perlu dilakukan adalah sebesar: Rp31.200.000,00 - Rp15.600.000,00 = Rp15.600.000,00.

Rekonsiliasi fiskal menyebabkan adanya perubahan penghasilan kena pajak perusahaan. Penghasilan kena pajak PT. Empat Tujuh Abadi Jaya mengalami perubahan dari Rp181.510.720,00 menjadi Rp273.080.000,00 dengan selisih Rp91.569.280,00. Menurut pasal 31E Undang-Undang No. 36 Tahun 2008 dikatakan bahwa peredaran bruto sampai dengan Rp50.000.000.000,00, untuk wajib pajak badan memperoleh pengurangan tarif 50\% 
dari tarif berdasarkan pasal 17 ayat (1) huruf b dan ayat (2a) atas penghasilan kena pajak yang merupakan bagian dari peredaran bruto sampai dengan Rp4.800.000.000,00. PT. Empat Tujuh Abadi Jaya merupakan wajib pajak badan yang dikenai tarif sebesar $25 \%$ menurut pasal 17 ayat (2a) UU No. 36 Tahun 2008. Dengan demikian, PT. Empat Tujuh Abadi Jaya dikenai tarif sebesar $50 \% \quad 25 \%=12.5 \%$.

Perhitungan pajak penghasilan:

$=$ Tarif Penghasilan Kena Pajak

$=12.5 \% \quad \mathrm{Rp} 273.080 .000,00$

$=$ Rp34.135.000,00

Penghitungan Pajak Penghasilan berdasarkan PPh Final 1\%. Hasil perhitungan pajak penghasilan PT. Empat Tujuh Abadi Jaya dengan menggunakan pajak penghasilan final $1 \%$ adalah sebesar Rp46.694.000,00. Hasil ini diperoleh dari penghasilan bruto per bulan dikalikan dengan tarif pajak sebesar 1\%, sehingga menghasilkan jumlah pajak penghasilan sebesar Rp46.694.000,00.

Perbandingan Pajak Penghasilan Berdasakan UU Pajak Penghasilan dan Pajak Penghasilan Final 1\%. Pajak penghasilan PT. Empat Tujuh Abadi Jaya dengan menggunakan undang-undang pajak penghasilan adalah sebesar Rp34.135.000,00. Sedangkan pajak penghasilan PT. Empat Tujuh Abadi Jaya dengan menggunakan pajak penghasilan final 1\% adalah sebesar Rp46.694.000,00. Penghitungan pajak penghasilan dengan undang-undang pajak penghasilan lebih sedikit apabila dibandingkan dengan pajak penghasilan final 1\% dengan selisih Rp12.559.000,00. Berdasarkan hasil penghitungan ini, dapat dilihat bahwa akan lebih efisien bagi PT. Empat Tujuh Abadi Jaya untuk menghitung pajak penghasilannya dengan menggunakan undang-undang pajak penghasilan dibandingkan dengan menggunakan pajak penghasilan final $1 \%$.

\subsection{Pembahasan}

Implikasi Pajak Penghasilan Final Terhadap Penghitungan Pajak Penghasilan. Penghitungan pajak penghasilan PT. Empat Tujuh Abadi Jaya dengan pajak penghasilan final memberikan perbedaan yang cukup berpengaruh. Perbedaan ini disebabkan karena perbedaan tarif dan dasar pengenaan pajak yang digunakan. Dengan menggunakan undang-undang pajak penghasilan, PT. Empat Tujuh Abadi Jaya dikenakan tarif sebesar 25\% yang mendapatkan fasilitas pengurangan tarif sebesar $50 \%$ menjadi $12,5 \%$. Sedangkan yang menjadi dasar pengenaan pajaknya adalah penghasilan neto perusahaan, didapatkan dengan hasil peredaran bruto yang dikurangi biaya-biaya yang digunakan. Apabila menggunakan pajak penghasilan final, tarif yang digunakan adalah $1 \%$. Dasar pengenaan pajak penghasilan final adalah peredaran bruto. Setiap biaya yang digunakan untuk menghasilkan laba, tidak dapat dikurangkan dalam peredaran bruto yang menjadi dasar pengenaan pajak. Peraturan ini tidak mentoleransi wajib pajak yang mengalami kerugian. Oleh karena itu, berbeda dengan undang-undang pajak penghasilan, apabila wajib pajak mengalami kerugian maka wajib pajak tetap harus membayar pajak penghasilan. Meskipun memberikan kemudahan dalam penghitungannya, namun nyatanya jumlah pajak penghasilan dengan menggunakan pajak penghasilan final $1 \%$ yang harus dibayarkan oleh PT. Empat Tujuh Abadi Jaya lebih besar apabila dibandingkan dengan menggunakan undang-undang pajak penghasilan. Selisih pajak penghasilan dengan menggunakan udang-undang pajak penghasilan dan pajak penghasilan final $1 \%$ adalah sebesar Rp12.559.000,00. Hal ini menunjukkan bahwa pajak penghasilan final $1 \%$ akan merugikan bagi wajib pajak badan yang memiliki laba neto yang kecil dan sebaliknya akan memberikan keuntungan bagi wajib pajak yang memiliki laba neto yang besar.

Penghitungan Pajak Penghasilan Berdasarkan PPh Final 0,5\%. Pajak penghasilan pada PT. Empat Tujuh Abadi Jaya dengan pajak penghasilan final 0,5\% adalah sebesar Rp23.347.000,00. Hasil ini didapatkan dari penghasilan bruto tiap bulan yang 
dikalikan dengan tarif $0,5 \%$ sehingga menghasilkan jumlah pajak penghasilan dengan menggunakan penghitungan tarif final 0,5\% sebesr Rp23.347.000,00. PT. Empat Tujuh Abadi Jaya diuntungkan apabila menggunakan pajak penghasilan final 0,5\% karena jumlah pajak penghasilan yang harus dibayarkan lebih kecil apabila dibandingkan dengan undangundang pajak penghasilan dengan selisih Rp10.788.000,00.

\section{KESIMPULAN DAN SARAN}

\subsection{Kesimpulan}

Berdasarkan hasil penelitian dan pembahasan yang dilakukan pada PT. Empat Tujuh Abadi Jaya, maka dapat diambil kesimpulan sebagai berikut:

1. Besarnya pajak penghasilan yang harus dibayar oleh PT. Empat Tujuh Abadi Jaya dengan menggunakan ketentuan undang-undang pajak penghasilan adalah sebesar Rp34.135.000,00.

2. Besarnya pajak penghasilan yang harus di bayar oleh PT. Empat Tujuh Abadi Jaya dengan menggunakan pajak penghasilan final 1\% adalah sebesar Rp46.694.000,00.

Selisih jumlah pajak penghasilan PT. Empat Tujuh Abadi Jaya dengan menggunakan undangundang pajak penghasilan dan pajak penghasilan final 1\% adalah Rp15.380.160,00, dengan jumlah pajak penghasilan berdasarkan undang-undang pajak penghasilan yang lebih kecil. Hal ini disebabkan jumlah penghasilan neto perusahaan yang kecil. Meskipun memberikan kemudahan dalam menghitung, menyetor, dan melaporkan pajak, namun nyatanya dengan menerapkan pajak penghasilan final 1\%, jumlah pajak yang harus dibayarkan oleh PT. Empat Tujuh Abadi Jaya lebih besar bila dibandingkan dengan undang-undang pajak penghasilan. Oleh karena itu, akan lebih efisien bagi PT. Empat Tujuh Abadi Jaya untuk menghitung pajak penghasilan berdasarkan undang-undang pajak penghasilan apabila dibandingkan dengan pajak penghasilan final $1 \%$.

\subsection{Saran}

Berdasarkan kesimpulan di atas, maka terdapat beberapa saran yang diberikan bagi PT. Empat Tujuh Abadi Jaya, antara lain:

1. Penghitungan pajak penghasilan PT. Empat Tujuh Abadi Jaya dengan menggunakan pajak penghasilan final 0,5\% adalah sebesar Rp23.347.000,00. Jumlah ini jauh lebih sedikit apabila dibandingkan dengan menggunakan undang-undang pajak penghasilan. Karena pengenaan pajak penghasilan final $0,5 \%$ bersifat opsional, maka mulai tanggal 1 Juli 2018, PT. Empat Tujuh Abadi Jaya dapat memilih untuk menggunakan pajak penghasilan final 0,5\% dalam hal ini PP No. 23 Tahun 2018.

2. Dengan menerapkan pajak penghasilan final 0,5\%, PT. Empat Tujuh Abadi Jaya lebih mudah dan sederhana dalam menentukan pajak penghasilannya.

3. Pajak penghasilan final $0,5 \%$ hanya dapat diterapkan selama tiga tahun oleh PT. Empat Tujuh Abadi Jaya. Oleh karena itu, selama menerapkan pajak penghasilan final 0,5\%, PT. Empat Tujuh Abadi Jaya harus belajar untuk melakukan pembukuan. Karena setelah masa tiga tahun berakhir, PT. Empat Tujuh Abadi Jaya harus menghitung pajak penghasilannya berdasarkan ketentuan undang-undang pajak penghasilan.

\section{DAFTAR PUSTAKA}

Ameyaw, Bismark, Joy Agyeman Korang, Evans Teddy Twum, dan Isaac Owusu Asante. 2016. Tax Policy, SMES Compliance, Perception and Growth Relationship in Ghana: An Empirical Analysis. British Journal of Economics, Management \& Trade 11(2): 111, 2016, Article no.BJEMT.22030. 
Hakim, Fadli, dan Grace B. Nangoi. 2015. Analisis Penerapan PP. No.46 Tahun 2013 Tentang Pajak Penghasilan UMKM Terhadap Tingkat Pertumbuhan Wajib Pajak dan Penerimaan PPh Pasal 4 Ayat (2) Pada KPP Pratama Manado. Jurnal EMBA: 787795. Vol.3 No.1 Maret 2015. ISSN 2303-1174.

Haryati, Ayu Putu Mirah, dan Naniek Noviari. 2016. Analisis Penerapan Peraturan Pemerintah No 46 Tahun 2013 Pada Besarnya Pajak Penghasilan. EJurnal Akuntansi Universitas Udayana: 2467-2493. Vol. 15. 3. Juni (2016) : 24672493. ISSN: 2302-8556.

Kartika, Yunitha Tri, dan Andri Waskita Aji. 2015. Analisis Pengaruh Pemahaman Ketentuan dan Presepsi Wajib Pajak Tentang Peraturan Pemerintah Nomor 46 Tahun 2013 Terhadap Kepatuhan Dalam Melaksanakan Ketentuan Pada Wajib Pajak Pelaku Usaha Mikro Kecil dan Menengah di Kota Yogyakarta. Jurnal Akuntansi: 5662, Vol. 3 No. 2 Desember 2015.

Mardiasmo. 2018. Perpajakan. Edisi Terbaru 2018. Penerbit Andi Offset. Yogyakarta.

Moleong, L. 2014. Metodologi Penelitian Kuantitatif. Penerbit PT. Remaja Rosdakarya. Bandung.

Natalia, Amanda, dan I Gusti Ayu Nyoman Budiasih. 2017. Analisis Penerapan Peraturan Pemerintah No. 46 Tahun 2013 Terhadap Tingkat Penerimaan Pajak di KPP Pratama Badung Selatan. E-Jurnal Akuntansi Universitas Udayana: 1861-1886. Vol.19.3. Juni (2017): 1861-1886. ISSN: 2302-8556.

Peraturan Pemerintah Republik Indonesia Nomor 46 Tahun 2013 Pajak Penghasilan Atas Penghasilan Dari Usaha Yang Diterima atau Diperoleh Wajib Pajak Yang Memiliki Peredaran Bruto Tertentu. 12 Juni 2013. Lembaran Negara Republik Indonesia Tahun 2013 Nomor 106. Jakarta.

Peraturan Pemerintah Republik Indonesia Nomor 23 Tahun 2018 Pajak Penghasilan Atas Penghasilan Dari Usaha Yang Diterima Atau Diperoleh Wajib Pajak Yang Memiliki Peredaran Bruto Tertentu. 8 Juni 2018. Lembaran Negara Republik Indonesia Tahun 2018 Nomor 89. Jakarta.

Resmi, S. 2014. Perpajakan Teori Dan Kasus. Edisi Keempat. Penerbit Salemba Empat. Jakarta.

Tohirin. 2012. Metode Penelitian Kualitatif. Penerbit PT. Raja Grafindo Persada. Jakarta.

Undang-Undang Republik Indonesia Nomor 17 Tahun 2000 Perubahan Ketiga Atas UndangUndang Nomor 7 Tahun 1983 Tentang Pajak Penghasilan. 2 Agustus 2000. Lembaran Negara Republik Indonesia Tahun 2000 Nomor 127. Jakarta.

Undang-Undang Republik Indonesia Nomor 28 Tahun 2007 Perubahan Ketiga Atas UndangUndang Nomor 6 Tahun 1983 Tentang Ketentuan Umum dan Tata Cara Perpajakan. 17 Juli 2007. Lembaran Negara Republik Indonesia Tahun 2007 Nomor 85. Jakarta.

Undang-Undang Republik Indonesia Nomor 36 Tahun 2008 Perubahan Keempat Atas Undang-Undang Nomor 7 Tahun 1983 Tentang Pajak Penghasilan. 23 September 2008. Lembaran Negara Republik Indonesia Tahun 2008 Nomor 133. Jakarta.

Widiati, Dinar Restu, Hestin Sri Widiawati, dan Dyah Ayu Paramitha. 2017. Analisis Sebelum dan Sesudah Penerapan PP 46 Tahun 2013 Terhadap Besarnya Pembayaran PPh Terutang PR. Cengkir Gading pada Tahun 2014 - 2016. SimkiEconomic: 1-16. Vol. 01 No. 01 Tahun 2017. 